\title{
Investigation of Mechanistic Pathway for Trimethyl Borate Mediated Amidation of (R)-Mandelic Acid for the Synthesis of Mirabegron, an Antimuscarinic Agent ${ }^{\#}$
}

\author{
Dattatray G. Deshmukh, ${ }^{1,2}$ Mukund N. Bangal, ${ }^{1}$ Mukunda R. Patekar, ${ }^{1}$ \\ Vijay J. Medhane ${ }^{2}$ and Vijayavitthal Thippannachar Mathad ${ }^{1, *}$ \\ ${ }^{1}$ Department of Process Research and Development, Megafine Pharma (P) Ltd., 201, Lakhmapur, Dindori, \\ Nashik-422 202, Maharashtra, India. \\ ${ }^{2}$ Organic Chemistry Research Center, Department of Chemistry, K. T. H. M. College, \\ Nashik-422 002, Maharashtra, India. \\ *Corresponding author: E-mail:vt.mathad@megafine.in,drvtmathad@yahoo.co.in
}

Received: 12-16-2017

"Megafine Publication Number: MF/027/2017

\begin{abstract}
The present work describes investigation of mechanistic pathway for trimethyl borate mediated amidation of $(R)$-mandelic acid (3) with 4-nitophenylethylamine (2) to provide (R)-2-hydroxy- $N$-[2-(4-nitrophenyl)ethyl]-2-phenylacetamide (4) during mirabegron synthesis. Plausible reaction mechanism is proposed by isolating and elucidating the active a-hydroxy ester intermediate $\mathbf{1 6}$ from the reaction mass. Trimethyl borate mediated approach proved to be selective in providing 4 without disturbing a-hydroxyl group and stereochemistry of the chiral center, and is also a greener, more economic and production friendly over the reported methods. The developed approach is rapid and efficient for the preparation of 4 with an overall yield of $85-87 \%$ and around $99.0 \%$ purity by HPLC at scale.
\end{abstract}

Keywords: Trimethyl borate, amidation, $\alpha$-hydroxy ester, antimuscarinic drug, mirabegron

\section{Introduction}

Mirabegron (1), chemically known as 2-(2-amino -1,3-thiazol-4-yl)-N-[4-(2-\{[(2R)-2-hydroxy-2phenylethyl]amino\}ethyl)phenyl]acetamide, is a selective agonist for the human beta 3 -adrenoceptor, ${ }^{1}$ approved for the treatment of overactive bladder $(\mathrm{OAB})$ syndrome. ${ }^{2}$ It exhibits novel mechanism of action compared to other antimuscarinics by improving the storage capacity of the bladder without inhibiting bladder voiding. ${ }^{3}$ The drug developed by Astellas Pharma was approved by the United States Food and Drug Administrative (US-FDA) in June 2012 and by European Medicines Agency in December $2012 .{ }^{4}$

The first generation syntheses, ${ }^{5}$ reported two synthetic approaches for $\mathbf{1}$ (Scheme 1, route a and b) wherein both the approaches follow opening of epoxide ring of the $(R)$-styrene oxide $(8)$. The first approach (Scheme 1, route a) involves nucleophilic addition of $\mathbf{2}$ on $\mathbf{8}$ to obtain nitro amine $\mathbf{5} \mathbf{a}$. The amino group of $\mathbf{5 a}$ is protected with di-tert -butyl-dicarbonate $\left(\mathrm{Boc}_{2} \mathrm{O}\right)$ to give $\mathbf{5 b}$ which is then reduced using $\mathrm{Pd} / \mathrm{C}$ to yield aniline derivative $\mathbf{6 a}$. Aniline $\mathbf{6 a}$ is further condensed with thiazole acid 7 to obtain amide intermediate 1a. Removal of Boc protection group of 1a using $\mathrm{HCl}$ furnished di-hydrochloride salt of $\mathbf{1}$ with an overall yield of around $8 \%$. In the second approach (Scheme 1 , route $b$ ), condensation of (4-aminophenyl)acetonitrile (9) and thiazole acid 7 is carried out in the first step, whereas advanced intermediate $11 \mathrm{a}$ is reacted with epoxide $\mathbf{8}$ in penultimate step to provide $\mathbf{1}$. However, detailed synthetic procedure for the route $b$ is not provided in the report. Both of these approaches have several disadvantages such as extensive use of protecting and de-protecting sequences, expensive $(R)$-styrene oxide $(\mathbf{8})$ as the starting material, and poor yields for epoxide ring opening reactions.

The second generation synthesis, ${ }^{6}$ (Scheme 1 , route c) reported for $\mathbf{1}$ exploited commercially available $(R)$ 
-mandelic acid (3) as the starting material instead of the epoxide 8. Synthesis commenced with coupling of 2 and 3 in the presence of 1-ethyl-3-(3-(dimethylamino)propyl) carbodiimide hydrochloride (EDCI) as the coupling agent, 1-hydroxybenzotriazole ( $\mathrm{HOBt}$ ) as the catalyst, triethylamine as the base in $\mathrm{N}, \mathrm{N}$-dimethylformamide (DMF) solvent to provide amide 4 . Amide 4 was reduced using borane-tetrahydrofuran $\left(\mathrm{BH}_{3}\right.$-THF) complex and 1,3 -dimethyl-2-imidazolidinone (DMI) to provide amino alcohol 5 which was hydrogenated under Pd-C catalyst to provide di-amine $\mathbf{6}$. Coupling of di-amine 6 with thiazole acid 7 in the presence of EDCI furnished 1 in its $\beta$-c- rystalline form. Finally, the $\beta$-crystalline form was crystallized in aqueous ethanol to obtain $\alpha$-crystalline form of 1 . Though the second generation synthesis represents an improvement over the first generation, it still has disadvantages, like the use of expensive EDCI in two steps which also poses increased burden of impurities due to side product formation from EDCI and HOBt. Other methods reported for 1 either involve use of expensive $(R)$ -styrene oxide (8) as the starting material resulting in low yields (around $11 \%$ to $27 \%$ ) or involve protection and de -protection steps that make the synthesis lengthy and less economic.?
First Generation Synthesis

Approach - I<smiles>NCCc1ccc([N+](=O)[O-])cc1</smiles><smiles>CC(C)(C)OC(=O)N(CCc1ccc([N+](=O)[O-])cc1)CC(O)c1ccccc1</smiles><smiles>CC(C)(C)OC(=O)N(CCc1ccc(N)cc1)CC(O)c1ccccc1</smiles><smiles>[3H]C(=O)Cc1csc(N)n1</smiles><smiles>Nc1nc(CC(=O)Nc2ccc(CCN(CC(O)c3ccccc3)C(=O)c3ccccc3)cc2)cs1</smiles><smiles>Nc1nc(CC(=O)Nc2ccc(CCNCC(O)c3ccccc3)cc2)cs1</smiles>
dihydrochloride of 1 H
Approach - II<smiles>N#CCc1ccc(N)cc1</smiles><smiles>[3H]c1nc(CC(=O)O)cs1</smiles><smiles>N#CCc1ccc(NC(=O)Cc2csc(N)n2)cc1</smiles>
$\mathrm{RaNi}, \mathrm{H}_{2}$<smiles>NCCc1ccc(NC(=O)Cc2csc(N)n2)cc1</smiles><smiles>Nc1nc(CC(=O)Nc2ccc(CCNCc3ccccc3)cc2)cs1</smiles><smiles>Nc1nc(CC(=O)Nc2ccc(CCN(Cc3ccccc3)CC(O)c3ccccc3)cc2)cs1</smiles><smiles>Nc1nc(CC(=O)Nc2ccc(CCNCC(O)c3ccccc3)cc2)cs1</smiles>

route b
Second Genaration Synthesis<smiles>NCCc1ccc([N+](=O)[O-])cc1</smiles><smiles>Nc1nc(CC(=O)Nc2ccc(CCNCC(O)c3ccccc3)cc2)cs1</smiles><smiles>Nc1nc(CC(=O)Nc2ccc(CCNCC(O)c3ccccc3)cc2)cs1</smiles>

route $\mathrm{c}$

Schemes 1. Reported syntheses of mirabegron (1).$^{5-6}$ 

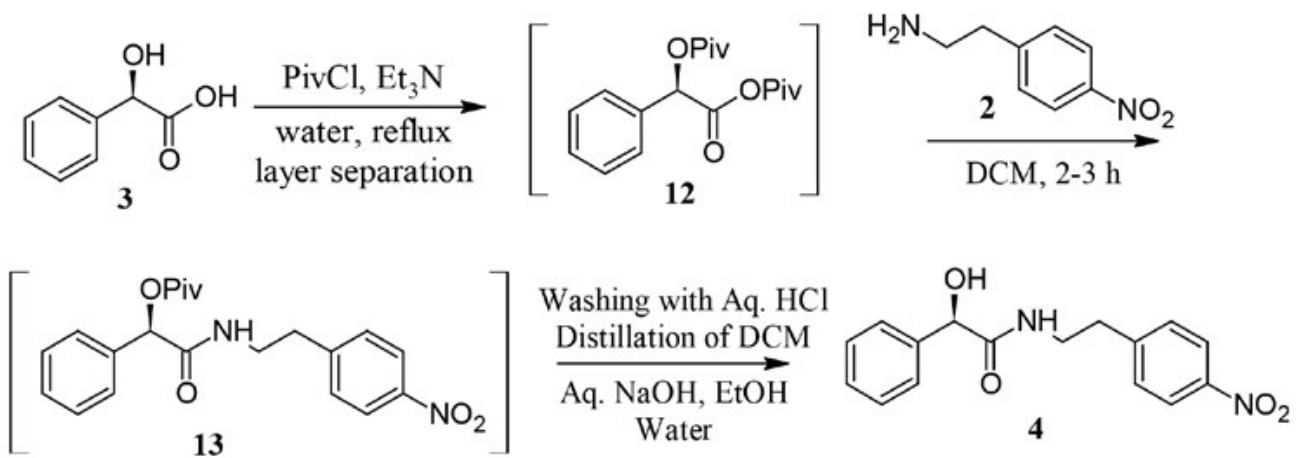

Scheme 2. Mixed anhydride approach ${ }^{8}$ for the synthesis of the key intermediate 4 .

Recent reported approach for the synthesis of 4 replaced EDCI and HOBt with pivaloyl chloride (PivCl) for the condensation of amine 2 with acid $\mathbf{3}$ via mixed anhydride approach in a biphasic medium comprising dichloromethane (DCM) and water in the presence of triethylamine at reflux temperature (Scheme 2). ${ }^{8}$

The organic layer containing mixed anhydride 12 (having both carboxylic acid groups and hydroxyl group of compound 3 protected with the pivaloyl group), is separated and reacted with amine 2 to obtain pivaloyl ether 13, which is hydrolyzed under basic conditions to provide the desired key intermediate 4. However, usage of $\mathrm{PivCl}$ at industrial scale with extended operations like separations, washings, de-protections and distillation makes the process cumbersome and less efficient.

Recently, we have reported ${ }^{9}$ an efficient and first process for the direct isolation of stable $\alpha$-form crystals of mirabegron (1) from our laboratory. In continuation of our research on mirabegron (1), herein, we report an easy, straightforward, industrially scalable, selective and economic synthesis of the key intermediate $(R)$-2-hydroxy- $N$ [2-(4-nitrophenyl)ethyl]-2-phenylacetamide (4) using trimethylborate as the coupling agent.

\section{Results and Discussion}

$(R)$-Mandelic acid (3) was found to be an appropriate starting point for mirabegron in view of the cost and commercial availability and was thus selected for the process research and development work (Scheme 1, route c). Use of EDCI and HOBt was not considered for the present work owing to the large quantity requirements and resulting in direct impact on the cost of production of $\mathbf{1}$. Thus, we began exploring alternatives to develop cost effective approach by employing simple, easily available and user friendly acid activating agents to manufacture large quantities of amide 4 . The commonly known methods for activation of carboxylic acid is to make its derivatives, such as acid halides, mixed anhydrides or to use activating agents, such as DCC, EDCI, HATU, HBTU, and BOP-Cl. Howe- ver, these methods have some disadvantages, for example, use of halogenating agents to prepare acid halides may affect chiral purity of $\mathbf{3}$, employing mixed anhydride method is not straightforward and requires additional efforts to overcome side product formation, ${ }^{10}$ and use of activating agents such as DCC, EDCI, HATU, HBTU, BOP-Cl and others does not only increases manufacturing cost but also increases burden of control of corresponding by-products in active pharmaceutical ingredient (API). ${ }^{10}$

Boric acid $\left[\mathrm{B}(\mathrm{OH})_{3}\right]$ and their derivatives are green, inexpensive and readily available catalysts for direct formation of amide bond, thus attracting our attention. ${ }^{11-14}$ We first attempted to carry out amidation between amine 2 and acid 3 using boric acid, including efforts of trapping water (i.e. side product) by means of molecular sieves and Dean-Stark apparatus but none of these attempts gave satisfactory results. As per literature reports, catalytic activity of boric acid was enhanced by converting it to borate esters by introducing mono-hydroxyl or di -hydroxyl functional groups, such as cresol or tetrachlorocatechol. ${ }^{15-16}$ However, to minimize the burden of atom economy, we attempted the use of a simple and commercially available trimethylborate $\left[\mathrm{B}(\mathrm{OMe})_{3}\right]$ as the coupling agent.

Feasibility of $\mathrm{B}(\mathrm{OMe})_{3}$ was explored during the screening experiments using various solvents [DMF, THF, 2Me-THF, acetonitrile (ACN), DMSO] in the presence of different bases (TEA, $\mathrm{K}_{2} \mathrm{CO}_{3}, \mathrm{NaHCO}_{3}$, DIPEA). The outcome of the screening experiments is shown in Table 1. Accordingly, the coupling reaction was proved to be successful when Hünig's base [ $N, N$-diisopropylethylamine (DIPEA)] was employed in acetonitrile as the solvent (Table 1, entry 7).

Further, to increase the yield and quality a set of optimization experiments were designed and executed. During the optimization it was observed that, when 2, 3, $\mathrm{B}(\mathrm{OMe})_{3}$ and DIPEA were added together in $\mathrm{ACN}$ and heated to reflux, $40-45 \%$ of amine 2 was found unreacted in the reaction mass even after 15 hours. On the contrary, when acid 3 and $\mathrm{B}(\mathrm{OMe})_{3}$ are allowed to react first in 
Table 1. Screening of coupling agent, solvent and base for amidation of $\mathbf{2}$ and $\mathbf{3}$.

\begin{tabular}{|c|c|c|c|c|c|c|c|c|}
\hline \multirow{2}{*}{ Entry } & \multirow{2}{*}{$\begin{array}{c}\mathrm{B}(\mathrm{OMe})_{3} \\
\text { (equiv.) }\end{array}$} & \multirow{2}{*}{$\begin{array}{l}\text { Solvent } \\
\text { (vol.) }\end{array}$} & \multirow{2}{*}{$\begin{array}{c}\text { Base } \\
\text { (equiv.) }\end{array}$} & \multirow{2}{*}{$\begin{array}{l}\text { Temp. } \\
\left({ }^{\circ} \mathrm{C}\right)\end{array}$} & \multirow{2}{*}{$\begin{array}{c}\text { Time } \\
\text { (h) }\end{array}$} & \multirow{2}{*}{$\begin{array}{l}\text { Unreacted } 2(\%) \\
\text { in reaction mass }\end{array}$} & \multicolumn{2}{|c|}{ Amide (4) } \\
\hline & & & & & & & Yield $^{1}(\%)$ & Purity $^{2}$ (\%) \\
\hline 1 & 2.0 & $\begin{array}{l}\mathrm{ACN} \\
(15)\end{array}$ & $\begin{array}{l}\text { TEA } \\
(2.0)\end{array}$ & reflux & 22 & 30.4 & 64.8 & 97.6 \\
\hline 2 & 2.0 & $\begin{array}{c}\mathrm{ACN} \\
(15)\end{array}$ & $\begin{array}{c}\mathrm{K}_{2} \mathrm{CO}_{3} \\
(2.0)\end{array}$ & reflux & 22 & 32.9 & 60.1 & 97.7 \\
\hline 3 & 2.0 & $\begin{array}{c}\mathrm{ACN} \\
(15)\end{array}$ & $\begin{array}{c}\mathrm{NaHCO}_{3} \\
(2.0)\end{array}$ & reflux & 22 & 54.9 & 54.0 & n.a. \\
\hline 4 & 2.0 & $\begin{array}{l}\text { THF } \\
(20)\end{array}$ & $\begin{array}{l}\text { DIPEA } \\
(2.0)\end{array}$ & reflux & 16 & 29.6 & 13.2 & n.a. \\
\hline 5 & 2.0 & 2-Me-THF (20) & $\begin{array}{l}\text { DIPEA } \\
(2.0)\end{array}$ & reflux & 21 & 21.4 & n.a. & 60.2 \\
\hline 6 & 2.0 & DCM (20) & $\begin{array}{l}\text { DIPEA } \\
(2.0)\end{array}$ & reflux & 23 & 61.9 & n.a. & n.a. \\
\hline 7 & 2.0 & $\begin{array}{l}\mathrm{ACN} \\
(15)\end{array}$ & $\begin{array}{c}\text { DIPEA } \\
(2.0)\end{array}$ & reflux & 21 & 25.9 & 74.3 & 98.6 \\
\hline
\end{tabular}

${ }^{1}$ Isolated yield; ${ }^{2}$ Percent purity of isolated $\mathbf{4}$ by HPLC; n.a: product not isolated.

ACN at elevated temperature followed by the addition of amine $\mathbf{2}$ and DIPEA, a drastic increase in product formation was observed leaving behind only $10-15 \%$ of unreacted amine 2 . To understand the reason behind higher conversion ratio, we conducted an investigation by trapping the reaction intermediate after reacting acid $\mathbf{3}$ and $\mathrm{B}(\mathrm{OMe})_{3}$ in $\mathrm{ACN}$. The solvent was distilled out completely, obtained oily residue was triturated in isopropyl ether and resultant gummy solid was analyzed by mass and NMR spectroscopy. The spectral data indicated the presence of $\mathbf{1 6}$ as the major constituent along with minor amounts of compounds $\mathbf{1 4}$ and $\mathbf{1 5}$ as per our primary investigation (Figure 1).
In order to confirm the structure of intermittent intermediate, the oily residue was further purified by column chromatography using ethyl acetate and $n$-heptane as the eluent over silica gel. The white crystalline solid obtained was analyzed by mass and NMR spectroscopy. The obtained spectral data confirmed the structure as methyl ester of $(R)$-mandelic acid (16), which was further confirmed by comparing it with methyl ester synthesized by reacting acid 3 and methanol in catalytic amounts of $\mathrm{HCl}$. Further, synthesized and isolated intermediates along with reaction mixture of acid 3 and $\mathrm{B}(\mathrm{OMe})_{3}$ were analyzed with HPLC using validated HPLC method and it was found that all the three components were eluted at the same<smiles>COB(OC(=O)C(O)c1ccccc1)OC(=O)C(O)c1ccccc1</smiles>

14<smiles>O=C(OB(O)OC(=O)[C@H](O)c1ccccc1)C(O)c1ccccc1</smiles>

15<smiles>COC(=O)C(O)c1ccccc1</smiles>

16

Figure 1. Plausible structures of intermediate during the coupling reaction.

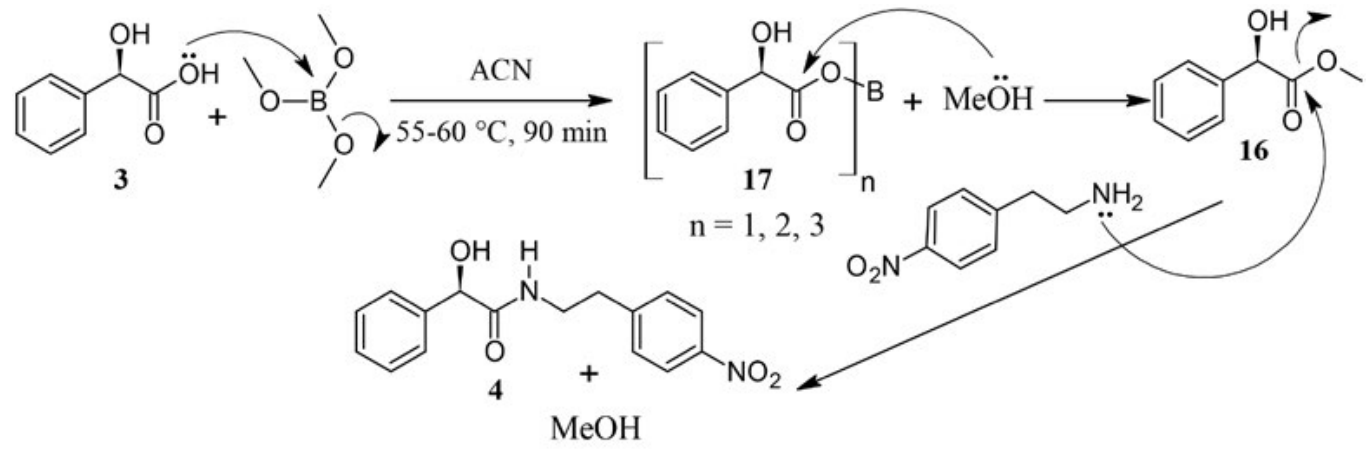

Figure 2. Proposed reaction mechanism for $\mathrm{B}(\mathrm{OMe})_{3}$ mediated synthesis of amide 4 . 
retention times confirming the proposed structure $\mathbf{1 6}$. Accordingly, we propose a plausible reaction mechanism (Figure 2) wherein acid 3 reacts with $\mathrm{B}(\mathrm{OMe})_{3}$ to form the activated borate ester intermediate $\mathbf{1 7}$ along with the byproduct methanol. Intermediate $\mathbf{1 7}$ undergoes nucleophilic reaction with methanol to form $\mathbf{1 6}$ which couples with $\mathbf{2}$ at reflux temperature to provide amide $\mathbf{4}$ selectively and efficiently.

Based on the above findings, the progress of the reaction was monitored by HPLC for formation of $\mathbf{1 6}$ and its subsequent conversion to amide 4. Further, appropriate reaction parameters were designed to achieve optimized reaction conditions (mole ratio of acid $3, \mathrm{~B}(\mathrm{OMe})_{3}$ and DIPEA with respect to amine 2 , volume of ACN, time and temperature) for the efficient synthesis of $\mathbf{4}$ from $\mathbf{2}$ and $\mathbf{3}$ via ester intermediate $\mathbf{1 6 .}$

Reacting $1.5 \mathrm{~mol}$ of acid 3 with $1.5 \mathrm{~mol}$ of $\mathrm{B}(\mathrm{OMe})_{3}$ at $55-60{ }^{\circ} \mathrm{C}$ for 90 minutes provided quantitative conversion to $\mathbf{1 6}$ as monitored by HPLC. However, temperature of more than $60^{\circ} \mathrm{C}$ led to the loss of $\mathrm{B}(\mathrm{OMe})_{3}$ due to evaporation. Amine $2(1.0 \mathrm{~mol})$ and DIPEA $(1.5 \mathrm{~mol})$ were then added to the above resulting mixture and heated to reflux temperature for 8-10 hours. Reaction mixture was monitored for the unreacted amine 2 that was consistently found $<5 \%$ after 8 to 10 hours. Once the desired conversion was achieved, solvent $\mathrm{ACN}$ was distilled to half of its initial volume followed by the addition of ethyl acetate and water to the resultant reaction mass. The organic layer from the above reaction mass was separated and washed with $10 \% \mathrm{HCl}$ solution to remove unreacted amine 2 and $5 \% \mathrm{NaOH}$ solution to remove unreacted acid 3 from the organic layer containing product 4. By-product boric acid gets washed out easily with aqueous phase. Organic layer was distilled out completely to provide crude 4 which was recrystallized from toluene to furnish pure amide 4 with $85-87 \%$ yield and $>98 \%$ purity by HPLC (Scheme 3). The experiments conducted to check the consistency of the established optimized reaction parameters are provided in Table 2.

\section{Conclusions}

In conclusion, we report an efficient, scalable and economic synthesis of amide 4, a key intermediate of mirabegron (1) prepared via an active ester intermediate $\mathbf{1 6 .}$ Based on the isolation and identification of the ester intermediate 16, a plausible mechanism for $\mathrm{B}(\mathrm{OMe})_{3}$ mediated synthesis of amide 4 is proposed. $\mathrm{B}(\mathrm{OMe})_{3}$ used for amide coupling in the present work is simple, cost efficient and easy to handle, therefore preferable over the other reported reagents. The developed process provided amide 4 in $85-$ $87 \%$ yield and $98.0-99.6 \%$ purity by HPLC on kilogram scale batches, which was further used in production of mirabegron API having high purity.

\section{Experimental Section}

\section{1. Materials}

All chemical reagents and solvents were purchased from Megafine Pharma (P) Ltd. Vapi, R. L. Chemical Industries Pvt. Ltd., Alkali metals Ltd., OC Specialties Pvt. Ltd. $\&$ Pacific Organics Pvt. Ltd. and Imperial Chemical Corporation and used as received.

\section{2. Instrumental Analysis}

The NMR spectra were recorded on Bruker Avance $300 \mathrm{MHz}$ instrument in DMSO- $d_{6}$; the chemical shifts are reported in $\delta$ ppm relative to TMS. Related substance purity and reaction monitoring were monitored by high performance liquid chromatography (HPLC) on Agilent Technologies 1200 series.

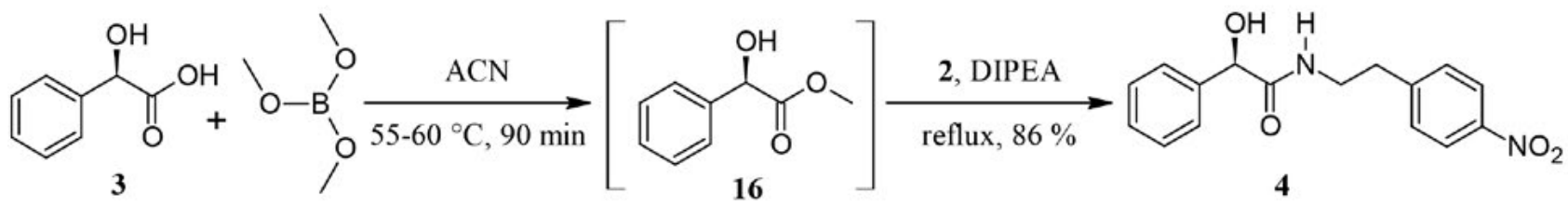

Scheme 3. $\mathrm{B}(\mathrm{OMe})_{3}$ mediated synthesis of amide 4 .

Table 2. Details of yield and purity after optimization for the synthesis of 4 .

\begin{tabular}{ccccccc}
\hline Entry & $\begin{array}{c}\text { B(OMe) } \\
\text { (equiv.) }\end{array}$ & $\begin{array}{c}\text { Solvent } \\
\text { vol. }(\mathbf{m L})\end{array}$ & $\begin{array}{c}\text { Base } \\
\text { (equiv.) }\end{array}$ & $\begin{array}{c}\text { Temp. } \\
\left({ }^{\circ} \mathbf{C}\right)\end{array}$ & $\begin{array}{c}\text { Time } \\
(\mathbf{h})\end{array}$ & $\begin{array}{c}\text { Amide (4) } \\
\text { Purity (\%) }\end{array}$ \\
\hline 1 & 1.5 & ACN (12) & DIPEA (1.5) & Reflux & 10 & 85.6 \\
2 & 1.5 & ACN (12) & DIPEA (1.5) & Reflux & 10 & 99.44 \\
3 & 1.5 & ACN (12) & DIPEA (1.5) & Reflux & 10 & 86.3 \\
4 & 1.5 & ACN (12) & DIPEA (1.5) & Reflux & 10 & 86.4 \\
\hline
\end{tabular}




\section{3. HPLC Method for Calculating the Chemical and Assay Purity}

Related substances, assay and chiral purity of mirabegron (1) were estimated by a gradient HPLC analysis method developed at Megafine.

a) Related substances of amide $\mathbf{4}$ was estimated by using Zorbax SB-C8, $(150 \times 4.6 \mathrm{~mm}$ ID), $3.5 \mu$ column; buffer comprising of phosphate buffer contains $3.4 \mathrm{~g}$ potassium dihydrogenorthophosphate in $1000 \mathrm{~mL}$ of HPLC grade water sonicated to dissolve, adjusted the $\mathrm{pH}$ to 6.5 with triethylamine and filtered through $0.45 \mu \mathrm{m}$ nylon filter and degased. Mobile phase-A comprising a mixture of buffer/ methanol in the ratio 80:20 (v/v). Mobile phase-B comprising a mixture of acetonitrile/methanol in the ratio $80: 20$ $(\mathrm{v} / \mathrm{v})$; gradient elution: time $(\mathrm{min}) / \mathrm{A}(\mathrm{v} / \mathrm{v}): \mathrm{B}(\mathrm{v} / \mathrm{v}), \mathrm{T}_{0^{\circ}} / 80: 20$, $\mathrm{T}_{8.0} / 80: 20, \mathrm{~T}_{25.0} / 65: 35, \mathrm{~T}_{40.0} / 65: 35, \mathrm{~T}_{43.0} / 80: 20, \mathrm{~T}_{50.0} / 80: 20$; flow rate $1.0 \mathrm{~mL} / \mathrm{min}$, column temperature $35^{\circ} \mathrm{C}$ wavelength 215 $\mathrm{nm}$. The observed retention time of amide 4 under these chromatographic conditions was about $15.0 \mathrm{~min}$.

b) Assay of amide 4 was estimated by using Zorbax SB-C8, $(150 \times 4.6 \mathrm{~mm}$ ID $), 3.5 \mu$ column; buffer was phosphate buffer containing $3.4 \mathrm{~g}$ potassium dihydrogenorthophosphate in $1000 \mathrm{~mL}$ of HPLC grade water, sonicated to dissolve, $\mathrm{pH}$ of 6.5 was adjusted with triethylamine and filtered through $0.45 \mu \mathrm{m}$ nylon filter and degased. Mobile phase comprising of buffer/acetonitrile in the ratio $60: 40(\mathrm{v} / \mathrm{v})$; flow rate $1.0 \mathrm{~mL} / \mathrm{min}$; column temperature $35^{\circ} \mathrm{C}$; wavelength $215 \mathrm{~nm}$. The observed retention time of amide $\mathbf{4}$ under these chromatographic conditions was about $4.7 \mathrm{~min}$.

\section{4. Preparation of Intermediate of $(R)$-mandelic Acid and Trimethyl Borate}

A solution of $(R)$-mandelic acid $(3,15 \mathrm{~g}, 98.6 \mathrm{mmol})$ and trimethyl borate $(10.26 \mathrm{~g}, 98.6 \mathrm{mmol})$ in acetonitrile $(150 \mathrm{~mL})$ was stirred at $55-60^{\circ} \mathrm{C}$. After $4.5 \mathrm{~h}$ TLC showed formation of a major spot, reaction mixture was adsorbed on silica gel and product was purified by column chromatography (silica gel: 60-120 mesh, eluent: 10\% ethyl acetate in $n$-heptane) providing $10.1 \mathrm{~g}$ pure crystalline solid. ${ }^{1} \mathrm{H}$ NMR (300 MHz, DMSO- $\left.d_{6}\right): \delta 7.41-7.29(\mathrm{~m}, 5 \mathrm{H}), 6.09-$ $6.07(\mathrm{~d}, J=5.1 \mathrm{~Hz}, 1 \mathrm{H}), 5.15-5.13(\mathrm{~d}, J=5.1 \mathrm{~Hz}, 1 \mathrm{H}), 3.6$ (s, 3H). ${ }^{1} \mathrm{H}$ NMR (300 MHz, DMSO- $d_{6}-\mathrm{D}_{2} \mathrm{O}$ Exchange): $\delta$ 7.41-7.29 (m, 5H), $5.14(\mathrm{~s}, 1 \mathrm{H}), 3.6(\mathrm{~s}, 3 \mathrm{H})$.

\section{5. Synthesis of Hydroxy-phenyl-acetic Acid Methyl Ester 16}

To a stirred solution of $(R)$-mandelic acid $(3,10 \mathrm{~g}$, $65.7 \mathrm{mmol})$ in methanol $(50 \mathrm{~mL})$ was added con. $\mathrm{HCl}(4$ $\mathrm{mL}$ ) and heated to $65^{\circ} \mathrm{C}$. After maintaining at that temperature for $5 \mathrm{~h}$ TLC showed complete conversion of 3 , thereafter methanol was distilled out and water $(100 \mathrm{~mL})$ was added to the residue. To the resultant mixture was added aq. $\mathrm{NaHCO}_{3}$ solution and the $\mathrm{pH}$ was adjusted between 7 and $8 . \mathrm{DCM}(50 \mathrm{~mL})$ was added and the mixture stirred for $5 \mathrm{~min}$. The layers were separated, and the organic layer was washed with $10 \% \mathrm{NaHCO}_{3}$ solution $(25 \mathrm{~mL})$ and $5 \%$ brine $(25 \mathrm{~mL})$. Organic layer was concentrated to yield hydroxy-phenyl-acetic acid methyl ester $\mathbf{1 6}$ as a white solid (7.5 g). ${ }^{1} \mathrm{H}$ NMR (300 MHz, DMSO- $\left.d_{6}\right): \delta 7.43-7.28$ (m, 5H), 6.10-6.08 (d, $J=5.1 \mathrm{~Hz}, 1 \mathrm{H}), 5.17-5.15(\mathrm{~d}, J=5.1$ $\mathrm{Hz}, 1 \mathrm{H}), 3.61(\mathrm{~s}, 3 \mathrm{H}) .{ }^{1} \mathrm{H}$ NMR $\left(300 \mathrm{MHz}\right.$, DMSO- $d_{6}-\mathrm{D}_{2} \mathrm{O}$ Exchange): $\delta 7.41-7.29(\mathrm{~m}, 5 \mathrm{H}), 5.14(\mathrm{~s}, 1 \mathrm{H}), 3.6(\mathrm{~s}, 3 \mathrm{H})$.

\section{6. Preparation of $(R)-2$-hydroxy- $N$-[2-(4- nitrophenyl)ethyl]-2-phenylacetamide (4)}

Acetonitrile (2.0 L), (R)-mandelic acid $(3,225.3 \mathrm{~g}$, $1.48 \mathrm{~mol})$ and trimethyl borate $(153.8 \mathrm{~g}, 1.48 \mathrm{~mol})$ was added into a RBF at $25-30{ }^{\circ} \mathrm{C}$ and stirred to obtain clear solution. The obtained clear solution was heated to $60^{\circ} \mathrm{C}$ for 90 min. Amine (2, $200 \mathrm{~g}, 0.987 \mathrm{~mol})$ and DIPEA (191 g, 1.48 mol) was added to the obtained solution at $60{ }^{\circ} \mathrm{C}$ and the reaction mixture was heated to reflux and stirred for $11 \mathrm{~h}$. Completion of the reaction was monitored by HPLC. Acetonitrile $(1.2 \mathrm{~L})$ was distilled at atmospheric pressure. The concentrated reaction mixture was cooled to $25-30^{\circ} \mathrm{C}$ and was diluted with ethyl acetate $(1.4 \mathrm{~L})$. Reaction mixture was then twice washed with $1 \mathrm{~N} \mathrm{HCl}(1.2 \mathrm{~L}$ and $0.8 \mathrm{~L})$ followed by washing with $5 \%$ sodium hydroxide solution $(1.2 \mathrm{~L}$ and $0.8 \mathrm{~L}$ ). Organic layer was further washed with $10 \%$ brine solution $(1.2 \mathrm{~L})$ and then concentrated under vacuum below $65^{\circ} \mathrm{C}$ to obtain residue. To the obtained residue toluene $(1.2 \mathrm{~L})$ was added, heated to $95^{\circ} \mathrm{C}$ for $30 \mathrm{~min}$, cooled to $20^{\circ} \mathrm{C}$ and stirred for $1-2 \mathrm{~h}$. Precipitated solid was filtered, washed with toluene $(100 \mathrm{~mL})$ and dried in a vacuum oven at $50 \pm 5^{\circ} \mathrm{C}$ for $2-3 \mathrm{~h}$. The dry weight of the amide 4 was 256 g (86.4\% yield). Purity by HPLC: $98.9 \% ; m / z[\mathrm{M}+\mathrm{H}]^{+}$calcd. for $\mathrm{C}_{16} \mathrm{H}_{16} \mathrm{~N}_{2} \mathrm{O}_{4}: 300.30$; found: $301 .{ }^{1} \mathrm{H} \mathrm{NMR}(300 \mathrm{MHz}$, DMSO- $d$ ): $\delta 2.85-2.88(\mathrm{t}, 2 \mathrm{H}), 3.29-3.43(\mathrm{~m}, 2 \mathrm{H}), 4.83-$ $4.84(\mathrm{~d}, 1 \mathrm{H}), 6.12-6.13(\mathrm{~d}, 1 \mathrm{H}), 7.23-7.31(\mathrm{~m}, 5 \mathrm{H}), 7.38-$ $7.40(\mathrm{~d}, 2 \mathrm{H}), 8.05-8.10(\mathrm{~m}, 3 \mathrm{H}) .{ }^{13} \mathrm{C}$ NMR $(75.5 \mathrm{MHz}$, DMSO- $\left.d_{6}\right): \delta 172.20,147.89,145.97,141.33,130.04,127.86$, $127.34,126.59,123.24,73.56,39.00,34.77$.

\section{Acknowledgment}

Authors thank the Management of Megafine Pharma (P) Ltd. for permission to publish this work. Authors also thank colleagues of the Analytical Research and Development team for their valuable inputs and support for this work.

\section{References}

\author{
1. J. Gras, Drugs Today 2012, 48, 25-32. \\ DOI:10.1358/dot.2012.48.1.1738056
}


2. T. Yamanishi, C. R. Chapple, K. Yasuda, K. Yoshida, R. Chess-Williams, Neurourology and Urodynamics 2003, 22, 338-342. DOI:10.1002/nau.10130

3. P. Tyagi, V. Tyagi, M. Chancellor, Expert Opin. Drug Saf. 2011, 10.2, 287-294. DOI:10.1517/14740338.2011.542146

4. New Class of Treatment for Overactive Bladder Approved in Europe, Astellas Pharma Europe Ltd., Chertsey, UK, $11^{\text {th }}$ January 2013. https://www.astellas.com/en/corporate/news/ pdf/131111_eg.pdf

5. T. Maruyama, T. Suzuki, K. Onda, M. Hayakawa, H. Moritomo, T. Kimizuka, T. Matsui, US Patent Number 6,346,532, date of patent Feb 12, 2002.

6. S. Kawazoe, K. Sakamoto, Y. Awamura, T. Maruyama, T. Suzuki, K. Onda, T. Takasu, US Patent Number 7,342,117, date of patent Mar 11, 2008.

7. R. Vedantham, B. Kandagatla, S. Vyala, V. V. N. K. V. Prasad Raju, P. Cherukupalli, J. Iqbal, V. H. Dahanukar, M. Kagga, R. Bandichhor, S. Oruganti, J. Chem. Pharm. Res. 2015, 7, 1473-1478.

8. L. Z. Qi, Y. Z. Zhi, D. L. Qing, M. Z. Zhan, X. Z. Fu, X. Z. Geng, Org. Process Res. Dev. 2016, 20, 1993-1996.

DOI:10.1021/acs.oprd.6b00231
9. D. G. Deshmukh, M. N. Bangal, A. C. Mali, V. J. Medhane, V. T. Mathad, Acta. Chim. Slov. 2017, 64, 461-466.

DOI: $10.17344 /$ acsi.2017.329

10. P. W. Tang, Org. Synth. 2005, 81, 262-272. DOI:10.15227/orgsyn.081.0262

11. K. Arnold, B. Davies, R. L. Giles, C. Grosjean, G. E. Smith, A. Witting, Adv. Synth. Catal. 2006, 348, 813-820.

DOI:10.1002/adsc.200606018

12. H. Charville, D. Jackson, G. Hodges, A. Whiting, Chem. Commun. 2010, 46, 1813-1823.

DOI:10.1039/b923093a

13. P. W. Tang, S. M. Dinh, P. Liu, Org. Synth. 2012, 89, 432-437. DOI:10.15227/orgsyn.089.0432

14. R. K. Mylavarapu, G. C. M. Kondaiah, N. Kolla, R. Veeramalla, P. Koikonda, A. Bhattacharya, R. Bandichhor, Org. Process Res. Dev. 2007, 11, 1065-1068.

DOI:10.1021/op700098w

15. P. Starkov, T. D. Sheppard, Org. Biomol. Chem. 2011, 9, 13201323. DOI:10.1039/c0ob01069c

16. T. Maki, K. Ishihara, H. Yamamoto, Org. Lett. 2006, 8, 14311434. DOI:10.1021/ol060216r

\section{Povzetek}

V članku opisujemo raziskavo mehanistične poti amidiranja (R)-mandljeve kisline (3) s 4-nitrofeniletilaminom (2) pod vplivom trimetil borata, ki vodi do nastanka $(R)$-2-hidroksi- $N$-[2-(4-nitrofenil)etil]-2-fenilacetamida (4), intermediata $\mathrm{v}$ sintezi mirabegrona. Na osnovi izolacije in karakterizacije aktivnega $\alpha$-hidroksiestrskega intermediata 16 iz reakcijske zmesi smo predlagali smiselen reakcijski mehanizem. Pristop z uporabo trimetil borata se je izkazal kot selektivna pot do spojine 4, saj stranska $\alpha$-hidroksi skupina reakcije ni motila, prav tako pa med reakcijo ni prišlo do racemizacije kiralnega centra. V primerjavi z doslej znanimi pristopi je opisana metoda okolju prijaznejša, bolj ekonomična in primernejša za industrijsko proizvodnjo. Metoda je hitra in učinkovita pot za pripravo 4 s celokupnim izkoristkom $85-87$ \% in približno $99.0 \%$ čistočo (ugotovljeno s HPLC). 